izv. prof. dr. sc. Lidija Lesko Bošnjak

Sveučilište u Mostaru, Ekonomski fakultet, Mostar, Bosna i Hercegovina lidija.lesko@ef.sum.ba

mr. sc. Mirela Mabić

Sveučilište u Mostaru, Ekonomski fakultet, Mostar, Bosna i Hercegovina mirela.mabic@ef.sum.ba

\title{
DRUŠTVENE MREŽE I ZAPOŠLJAVANJE: PRAKSA I STAVOVI POSLODAVACA U BOSNI I HERCEGOVINI
}

Primljeno: 4. studeni 2019.

Prihvaćeno: 11. studeni 2019.

Pregledni rad

\section{Sažetak}

Upotreba interneta i društvenih mreža neizostavan je segment u poslovanju suvremenih organizacija. Osim za promoviranje svojih aktivnosti poslodavci društvene mreže sve više koriste i u procesu pribavljanja i selekcije zaposlenika.

Osnovni cilj rada je istražiti praksu i stavove poslodavaca u Bosni i Hercegovini vezano za korištenje i percipiranje vrijednosti društvenih mreža kao jednog od alata u procesu zapošljavanja.

Empirijsko istraživanje provedeno je tijekom svibnja i lipnja 2019. godine. Anketni upitnik su pripremile autorice, a distribuiran je online. Na sudjelovanje je pozvano 300, a odazvala su se 62 poduzé́a. Za prikaz rezultat korištene su apsolutne i relativne frekvencije, mjere deskriptivne statistike, a za testiranje značajnosti razlika korišteni su t test za nezavisne uzorke, ANOVA, Mann-Whitney U test te Kruskal-Wallis H test. Rezultati istraživanja pokazuju da iako $82 \%$ ispitanih poslodavaca navodi da društvene mreže koristi u svom poslovanju svega polovina njih prepoznaje društvene mreže kao vrijedan alat u procesu pribavljanja i selekcije zaposlenika. Kao razloge zašto se društvene mreže nedovoljno koriste poslodavci navode da koriste usluge agencija za zapošljavanje, zapošljavaju po preporuci, imaju formiranu bazu potencijalnih kandidata, a dio poslodavaca ih smatra i neadekvatnim alatom u kontekstu upravljanja ljudskim potencijalima. 
Kao ograničenja istraživanja treba prvenstveno navesti veličinu uzorka te upoznatost s društvenim mrežama općenito. Korišteni uzorak ne dopušta donošenje općih zaključaka za Bosnu i Hercegovinu no istraživanje daje temelje za sagledavanje stanja i trendova vezano za upotrebu društvenih mreža u kontekstu zapošljavanja.

Ključne riječi: društvene mreže, zapošljavanje, poslodavci, Bosna i Hercegovina;

JEL: O15, L86

\section{UVOD}

Pretpostavka uspješnog poslovanja svakako je zapošljavanje odgovarajućeg broja kvalitetnih ljudi koji će svojim radom pridonijeti ostvarenju postavljenih ciljeva. Stoga poslodavci u procesu pribavljanja trebaju osigurati odgovarajući broj dovoljno kvalificiranih kandidata, kojima je posao prihvatljiv, a između kojih će se odabrati oni najbolji. U osiguranju pravog broja kvalitetnih i stručnih zaposlenika poslodavci trebaju provesti niz informativnih aktivnosti kako bi se potencijalni kandidati upoznali ne samo s poslovima za koje bi se mogli natjecati, nego i njihovim mogućim položajem u organizaciji (kompenzacije, beneficije, mogućnosti razvoja karijere i dr.). Na proces pribavljanja potencijalnih kandidata utječe i ugled poduzeća u javnosti. Poduzeća koja imaju dobar imidž, odnosno koja su na dobrom glasu lakše će pronaći i pridobiti kvalificirane ljude. Nakon pribavljanja kandidata slijedi selekcija, odnosno izbor onih koji najbolje odgovaraju zahtjevima posla za koji su se prijavili. Selekcija kandidata kao funkcija menadžmenta ljudskih potencijala je posebno važna jer sve kasnije aktivnosti i ukupna uspješnost organizacije ovise o tome kakvi su ljudi izabrani. Važnost selekcijskih odluka se ogleda u tome što one bitno utječu na buduće troškove i dobit organizacije. Osim toga, loš odabir djelatnika ne utječe samo na loše izvršavanje njihovih zadatka već i na rad drugih, jer ih oni ometaju, frustriraju, demotiviraju i slično. Sve su to razlozi zbog kojih uspješne organizacije ulažu sve više novca, vremena i stručnih znanja na organiziranje dobrog procesa selekcije. Osim utvrđivanja zahtjeva posla i potrebnih osobina i kvaliteta kandidata, u procesu organiziranja selekcijskog postupka potrebno je definirati i odgovarajuće metode i tehnike, odnosno izvore informacija o kandidatima, kako bi se ispitalo imaju li i u kojem stupnju kandidati zahtijevane osobine.

U novije vrijeme u procesu pribavljanja i selekcije zaposlenika svoje mjesto sve više nalaze i društvene mreže. Društvene mreže su Web 2.0 aplikacije koje pojedincima omogućuju provedbu velikog broja različitih online aktivnosti počevši 
od izrade i personalizacije osobne stranice preko povezivanja, komunikacije i suradnje sa korisnicima sličnih interesa pa sve do razmjene raznovrsnih sadržaja (Orehovački, 2013). Obično se klasificiraju u tri temeljne skupine. U prvu skupinu se ubrajaju opće društvene mreže čiji su najpoznatiji predstavnici Facebook i Google+. Osnovni motivi upotrebe ove skupine društvenih mreža su vezani uz izražavanje osobnog identiteta, diseminaciju sadržaja te različite oblike interakcije s kontaktima (Pempek, Yermolayeva i Calvert, 2009). U drugu skupinu se ubrajaju društvene mreže kao što su Linkedln i ResearchGate koje su namijenjene povezivanju znanstvenika i stručnjaka, razmjeni znanja i iskustava, izradi osobnih portfelja te diseminaciji projektnih rezultata (Orehovački, 2013). Posljednju skupinu društvenih mreža čine platforme poput Ning-a i SocialGo-a koje služe razvoju vlastitih izoliranih i specijaliziranih interesnih zajednica.

Općenito, u današnjem dinamičnom okruženju upotreba društvenih mreža pridonosi uštedi vremena pri traženju, razmjeni i korištenju informacija te uštedi sredstava pri uspostavi, razvijanju i održavanju željenih kontakata. U kontekstu zapošljavanja pojava društvenih mreža omogućila je poslodavcima da jednostavnije i brže dođu do određenih informacija o potencijalnim kandidatima, a kandidatima su pružene daleko šire mogućnosti u pogledu kontaktiranja poslodavaca i dobivanja odgovarajućeg zaposlenja.

U svijetu se na društvenim mrežama nalazi oko 2,8 milijardi ljudi. Više od 73\% ljudi u dobi od 18 do 34 godine posao je pronašlo putem društvenih kanala (Hudson, 2019). Doda li se ovome spoznaja kako sve više poslodavaca koriste društvene mreže prije intervjua da bi „upoznali“ kandidata jasno je da se radi o mediju koji je svakako potreban u procesu zapošljavanja.

Društvene mreže procesu pribavljanja i selekcije novih zaposlenika donose niz prednosti, ali i nedostataka. Tako Cober, Brown, Blumental, Doverspike i Levy (2000) navode da korištenje društvenih mreža u procesu pribavljanja novih zaposlenika smanjuje troškove zapošljavanja do $95 \%$, a vrijeme trajanja ciklusa zapošljavanja se može skratiti za $25 \%$. Prema istraživanju koje je proveo CareerBuilder.com skoro polovina američkih menadžera navodi da za istraživanje kandidata za posao koristi društvene mreže (Kluemper, Mitra i Wang, 2016). Najčešće ih koriste prilikom zapošljavanja novih zaposlenika na poslove u informatičkoj industriji te profesionalnim i poslovnim uslugama, a najčešće se pregledavaju profili na Facebooku, LinkedInu i MySpaceu. Kako navode Fallaw i Kantrowitz (u Jovandić, 2014) poslodavci na društvenim mrežama najčešće pretražuju podatke: o prethodnom poslu (55\%), obrazovanju (50\%), preporuke (41\%), druge podatke o kandidatu - npr. hobiji, interesima (33\%), fotografije (28\%), članstvo u grupama (24\%), komentari i drugi sadržaji koje kandidat postavlja (18\%). 
Što se tiče pouzdanosti, skoro polovina menadžera smatra da podaci dostupni na društvenim mrežama nisu pouzdani, ali mogu otkriti i jedinstvene informacije koje se odnose na potencijalnog zaposlenika (Davison, Maraist, Hamilton i Bing, 2012).

Zanimljivo je istaknuti da trećina poslodavaca navodi kako je nakon pregledavanja podataka o kandidatima za posao dostupnima na društvenim mrežama kandidate odbilo. Kao razlozi odbijanja navode se: provokativne ili neprimjerene fotografije ili informacije, sadržaj o konzumiranju alkohola ili droge, loša iskustva s prethodnim poslodavcem, loše komunikacijske vještine, laganje o kvalifikacijama i dijeljenje povjerljivih informacija od prethodnog poslodavca (Kluemper et al, 2016). No, isto tako petina poslodavaca navodi da je pojedine kandidate za posao zaposlila upravo zahvaljujući podacima dostupnima na društvenim mrežama. Razlozi za to su bili dobro organiziran profil, podaci na profilu koji potvrđuju kvalifikacije kandidata za posao, dobre komunikacijske vještine, pozitivne preporuke drugih (Kluemper et al, 2016).

Međutim, posebno treba istaknuti da profili na društvenim mrežama ne otkrivaju nužno i pravu sliku o pojedincu te da neki ljudi zabrinuti za svoju sigurnost ne iznose dovoljno informacija na internetu, odnosno društvenim mrežama. Stoga i ne čudi podatak da se svega $11 \%$ menadžera ljudskih potencijala izjasnilo da su informacije sa društvenih mreža presudne za zapošljavanje kandidata, a 12\% ih je potvrdilo potpuno povjerenje u kvalitetu informacija koje tamo nalazi (Fallaw i Kantrowitz, 2013).

Ono što je sigurno, uključivanje društvenih mreža u proces zapošljavanja značajno povećava populaciju potencijalnih zaposlenika, ali istovremeno i usložnjava privlačenje kvalificiranih kandidata (Boehle, 2000).

Skrining profila na društvenim mrežama potencijalnih zaposlenika je posebno zastupljen u SAD-u, ali i tamo znatno ovisi od djelatnosti i radnog mjesta te pokazuje trend promjene $u$ vrsti društvenih mreža koje se analiziraju prilikom zapošljavanja kandidata. Fokus se pomjera s Facebooka na više profesionalno fokusirane društvene mreže poput LinkedIna (Kluemper, McLarty i Rosen, 2013).

Prema istraživanju Jobvite u 2018. godini LinkedIn je na prvom mjestu po upotrebi društvenih mreža u procesu pribavljanja zaposlenika sa $77 \%$, dok je Facebook na drugom mjestu sa $63 \%$. U odnosu na godinu prije LinkedIn je zabilježio pad za čak $15 \%$, a u procesu pribavljanja poslodavci, posebice oni mlađi, sve više pregledavaju i Instagram - 25\%.

Ako promatramo naše susjedne zemlje prema podacima Infostuda $58 \%$ poslodavaca u Srbiji dodatne informacije o kandidatima traži na društvenim mrežama, i 
to prvenstveno na poslovnoj društvenoj mreži LinkedIn, a rjeđe na Facebooku i Twitteru (Jovandić, 2014). Prema istraživanju koje je proveo MojPosao (2017) većina ispitanih poslodavaca u Hrvatskoj $(\mathrm{n}=15)$ priznala je kako provjeravaju kandidate za posao na društvenim mrežama čija primarna svrha nije traženje posla.

U svakom slučaju, da bi društvene mreže u poslovanju što više bile koristan alat potrebno je poduzeti odgovarajuće mjere kako bi se zaštitili povjerljivi podaci i informacije kako o samim zaposlenicima tako i o poduzeću te na taj način smanjili rizici njihove zlouporabe. Osim toga, potrebno je voditi računa da korištenje društvenih mreže na radnom mjestu bude usmjereno na ostvarivanje konkretnih i korisnih zadataka koji će pridonijeti povećanju radne učinkovitosti, a ne nekih aktivnosti koje će ometati zaposlenike u njihovom radu.

Cilj rada je istražiti praksu i stavove poslodavaca u Bosni i Hercegovini o mogućnostima i potrebi korištenja društvenih mreža u procesu zapošljavanja. Odnosno, saznati koliko poslodavci koriste društvene mreže u poslovanju, a posebice koliko ih koriste za oglašavanje slobodnih radnih mjesta te prikupljanje podataka i informacija o potencijalnim kandidatima.

Kroz istraživanje se, između ostalog, nastojalo dobiti odgovore na pitanja percipiraju li poslodavci društvene mreže kao alat koji može proces pribavljanja i selekcije zaposlenika učiniti jednostavnijim, bržim i jeftinijim te koliko poslodavci društvene mreže smatraju pouzdanim izvorom informacija za donošenje odluke o izboru novih zaposlenika.

Osim tog, cilj je i utvrditi postoje li značajne razlike u stavovima ispitanika s obzirom na karakteristike poduzeća iz kojih dolaze te dosadašnju/trenutnu praksu korištenja društvenih mreža u poslovanju, za oglašavanje slobodnih radnih mjesta te informiranje o potencijalnim kandidatima. Pretpostavka je da su poduzeća koja društvene mreže koriste u svom poslovanju i pojedinim aktivnostima vezanima za zapošljavanje novih djelatnika prepoznale $\mathrm{i}$ iskusile njihove koristi $\mathrm{u}$ navedenom procesu što bi se u rezultatima manifestiralo kroz razlike u ocjenama istraživanih faktora pri čemu bi ova skupina poduzeća imala veće ocjene od poduzeća koja ih ne koriste.

Strukturu rada čini pet cjelina. Nakon uvodnog dijela o procesu pribavljanja i selekcije zaposlenika, društvenim mrežama i njihovoj povezanosti slijedi metodologija u kojoj je opisan uzorak na kojem je provedeno empirijsko istraživanje, instrument korišten u istraživanju te statistička obrada podataka. Rezultati donose osnovne informacije o praksi korištenja društvenih mreža među poslodavcima te njihove stavove o društvenim mrežama u kontekstu zapošljavanja. Slijedi 
rasprava s osvrtom na dobivene rezultate. Rad završava zaključnim razmatranjima o implikacijama dobivenih rezultata te smjerovima daljnjih istraživačkih aktivnosti.

\section{METODOLOGIJA ISTRAŽIVANJA}

Anketni upitnik korišten u istraživanju pripremile su autorice na temelju sličnih istraživanja dostupnih u literaturi. Upitnik je podijeljen u tri cjeline. Prva cjelina je sadržavala pitanja o karakteristikama poduzeća iz kojih dolaze ispitanici (pitanja su prikazana u tablici 1). Druga cjelina je sadržavala pitanja o trenutnoj praksi korištenja društvenih mreža u procesu zapošljavanja novih djelatnika u poduzećima u kojima su zaposleni ispitanici. U trećoj cjelini upitnika ispitanicima je ponuđen set od 12 tvrdnji kojim se nastojao ispitati njihov stav o korištenju društvenih mreža u procesu zapošljavanja novih djelatnika. Ispitanici su zamoljeni da tvrdnje ocjene na Likertovoj petostupanjskoj ljestvici slaganja sa sljedećim značenjem ocjene: 1 - nikako se ne slažem; 2 - ne slažem se; 3 - niti se slažem niti se ne slažem (nemam mišljenje); 4 - slažem se; 5 - u potpunosti se slažem. Za popunjavanje upitnika je trebalo odvojiti 5-7 minuta.

Provedeno je online istraživanje. Anketni upitnik je kreiran korištenjem opcija Google-ovih obrazaca te je link na anketni upitnik poduzećima poslan putem maila. Odgovori poduzeća su bilježeni u Microsoft Excel 2007. Prikupljeni podaci su prekodirani i uneseni u bazu podataka u SPSS-u. Podaci su analizirani u programu IBM SPSS Statistics, verzija 25. Kategorijalne varijable su iskazane kao apsolutne i relativne frekvencije (\%). Numeričke varijable su iskazane kao aritmetička sredina i standardna devijacija $(\mathrm{M} \pm \mathrm{SD})$ odnosno medijan i interkvartili raspon (M [IQ]) ovisno o normalnosti distribucije pojedinih varijabli. Za testiranje značajnosti razlika su korišteni t test za nezavisne uzorke, ANOVA, Mann-Whitney U test te Kruskal-Wallis H test. Granica statističke značajnosti je postavljena na $\mathrm{p}=0.05$. P vrijednosti koje se nisu mogle iskazati do tri decimalna mjesta su iskazane kao $\mathrm{p}<0,001$.

Empirijsko istraživanje je provedeno u Bosni i Hercegovini tijekom svibnja i lipnja 2019. godine. Na sudjelovanje u istraživanju je pozvano 300 poduzeća, a odazvalo ih se 62, stopa povrata je 20,66\%. Poduzećima je na službeni mail dostupan na službenim stranicama poslan mail s linkom na kojem se nalazila anketa. Od njih 300 za 39 se odmah nakon slanja dobila poruka o neispravnoj mail adresi, a 5 poduzeća/ispitanika je poslalo povratni mail u kojem je navelo da ne žele sudjelovati u istraživanju (nemaju vremena, ne zanima ih tematika istraživanja, ..). Stvarna stopa povrata, ako se isključe poduzeća s pogrešnim mail adresama je 23,75\%. Karakteristike poduzeća u kojima rade ispitanici su prikazane u tablici 1. 
Tablica 1. Karakteristike poduzeća

\begin{tabular}{|c|c|c|}
\hline & & $\begin{array}{c}\text { Broj (\%) poduzeća } \\
(\mathrm{n}=62)\end{array}$ \\
\hline \multirow{3}{*}{$\begin{array}{c}\text { Razdoblje osnivanja po- } \\
\text { duzeća }\end{array}$} & prije 1990. god. & $14(22,6)$ \\
\hline & 1990. - 2000. god. & $27(43,5)$ \\
\hline & nakon 2000. god. & $21(33,9)$ \\
\hline \multirow{4}{*}{ Broj zaposlenih } & manje od 10 & $12(19,4)$ \\
\hline & između 10 i 50 & $12(19,4)$ \\
\hline & između 50 i 250 & $22(35,5)$ \\
\hline & više od 250 & $16(25,8)$ \\
\hline \multirow{3}{*}{ Oblik vlasništva } & Državno & $6(9,7)$ \\
\hline & Privatno & $53(85,5)$ \\
\hline & Mješovito & $3(4,8)$ \\
\hline \multirow{3}{*}{ Vlasnička struktura } & domaći vlasnici & $44(71,0)$ \\
\hline & strani vlasnici & $11(17,7)$ \\
\hline & mješovito vlasništvo & $7(11,3)$ \\
\hline \multirow{2}{*}{$\begin{array}{l}\text { U poduzeću postoji odjel } \\
\text { ljudskih resursa }\end{array}$} & da & $26(41,9)$ \\
\hline & ne & $36(58,1)$ \\
\hline \multirow{3}{*}{ Djelatnosti } & Sekundarne & $15(24,2)$ \\
\hline & Tercijarne & $40(64,5)$ \\
\hline & Kvartarne & $7(11,3)$ \\
\hline
\end{tabular}

Izvor: priprema autorica

Nad setom tvrdnji korištenih u istraživanju je provedena faktorska analiza, a rezultati su pokazali da su podaci pogodni za faktorsku analizu: Kaiser-Meyer-O1kinova mjera iznosi 0,811, a Bartlettov test sferičnosti je značajan, $\mathrm{p}<0,001$.

Faktorska analiza (varimax rotacija s Kaiserovom normalizacijom) je nakon 5 iteracija rezultirala s 3 faktora koju su uključili 11 tvrdnji od njih 12 . Spomenutim faktorima je objašnjeno 70,38\% varijance, a svi faktori imaju dobru unutarnju konzistentnost (tablica 2).

Tablica 2. Karakteristike faktora

\begin{tabular}{ccc}
\hline Naziv faktora & $\begin{array}{c}\text { Broj } \\
\text { tvrdnji }\end{array}$ & $\begin{array}{c}\text { Cronbach's } \\
\text { Alpha }\end{array}$ \\
\hline Korisnost & 7 & 0,903 \\
\hline Presudnost & 2 & 0,838 \\
\hline Pouzdanost & 2 & 0,702 \\
\hline
\end{tabular}

Izvor: priprema autorica 
Ocjene faktora su formirane kao aritmetička sredina ocjena tvrdnji koje čine pojedini faktor.

\section{REZULTATI ISTRAŽIVANJA}

Od 62 ispitana poslodavca njih 51 (82,3\%) je navelo da u svom poslovanju koriste društvene mreže. Najzastupljenija društvena mreža je Facebook (48/51 poduzeća), slijedi Instagram (34/51 poduzeća), LinkedIn (17/51 poduzeća) te Twitter koji koristi 10 poduzeća.

Što se tiče broja društvenih mreža koja pouzeća koriste raspodjela pokazuje da ih 14 koristi samo jednu društvenu mrežu, 21 dvije, a 10 tri.

Prema odgovorima ispitanika, polovina poduzeća (njih 31; 50,0\%) društvene mreže koristi za oglašavanje slobodnih radnih mjesta, dok jedno poduzeće manje (njih 30; 48,4\%) društvene mreže koristi za prikupljanje podataka i informacija o potencijalnim kandidatima za poslove koje oni nude. Ispitanici koji su na ova dva pitanja dali pozitivan odgovor za svoje poduzeće su zamoljeni da daju ocjenu svog zadovoljstva društvenim mrežama. Tako je utvrđeno da svoje zadovoljstvo korištenjem društvenih mreža za oglašavanje slobodnih radnih mjesta ocjenjuju prosječnom ocjenom 3,9 ( $\mathrm{SD}=0,94)$, a zadovoljstvo korištenjem društvenih mreža za prikupljanje podataka i informacija o potencijalnim kandidatima prosječnom ocjenom $3,6(\mathrm{SD}=0,93)$.

S druge pak strane, ispitanici koji su dali negativne odgovore su zamoljeni da navedu razloge zašto društvene mreže ne koriste u kontekstu zapošljavanja. Između ostalog, kao razloge zašto njihovo poduzeće društvene mreže ne koristi za oglašavanje slobodnih radnih mjesta su naveli sljedeće:

- „koristimo usluge agencija za zapošljavanje“,

- ,zapošljavamo samo po preporuci suradnika“,

- „mi smo mala firma, obiteljskog karaktera“,

- „društvene mreže smatramo neadekvatnim medijem za oglašavanje slobodnih radnih mjesta“,

- Svakodnevno primamo životopise/prijave potencijalnih kandidata“,

- „radimo u specifičnoj industriji“,

- „u pravilnicima firme je definirano kako se i gdje oglašavaju slobodna radna mjesta, društvene mreže nisu predviđene za to",

- ,koristili smo, ali više ne, jer se pokazalo da se tako prijavi znatno više nezadovoljavajućih i neozbiljnih kandidata“". 
Što se pak tiče razloga zbog kojih prilikom selekcije kandidata ne konzultiraju i društvene mreže, odnosno ne pregledaju profile potencijalnih kandidata ispitanici su naveli sljedeće:

- „društvene mreže daju krivu sliku o mogućim uposlenicima“,

- „nismo imali potrebu za takvim načinom prikupljanja podataka“,

- „interno pravilo kompanije“,

- „društvene mreže ne smatramo relevantnim izvorom informacija“,

- „nismo razmišljali o toj opciji“,

- zapošljavamo samo prema preporukama“.

Koje bi stavke, po mišljenju ispitanika (bez obzira na njihovu dosadašnju/trenutnu praksu korištenja društvenih mreža u procesu pribavljanja i selekcije kadrova), poslodavci, za kandidate (buduće zaposlenike), trebali pogledati (provjeriti) na društvenim mrežama prikazuje tablica 3 .

Tablica 3.

\begin{tabular}{cc}
\hline & $\begin{array}{c}\text { Broj (\%) } \\
\text { poduzeća }\end{array}$ \\
\hline podaci o prethodnom poslu & $35(56,5)$ \\
\hline podaci o obrazovanju & $36(58,1)$ \\
\hline preporuke & $23(37,1)$ \\
\hline podaci o hobijima, interesima & $25(40,3)$ \\
\hline slike/fotografije & $21(33,9)$ \\
\hline izjave o interesima i aktivnostima & $25(40,3)$ \\
\hline pripadnost ili članstvo nekim grupama & $18(29,0)$ \\
\hline komentari i druge sadržaji koje kandidat objavljuje & $23(37,1)$ \\
\hline komentari i druge sadržaji koje objavljuju prijatelji kandidata & $6(9,7)$ \\
\hline
\end{tabular}

Izvor: priprema autorica

Ocjene faktora kako za cijeli uzorak tako i prema dosadašnjoj/trenutnoj praksi korištenja društvenih mreža u procesu pribavljanja i selekcije zaposlenika su prikazane u tablici 4.

Tablica 4.

\begin{tabular}{|c|c|c|c|c|}
\hline \multirow{2}{*}{$\begin{array}{c}\text { Koriste } \\
\text { društvene mreže }\end{array}$} & & Korisnost & Presudnost & Pouzdanost \\
\hline & $\begin{array}{c}\text { Cijeli } \\
\text { uzorak }\end{array}$ & $3,62 \pm 0,85$ & $2,38 \pm 1,05$ & $3,80 \pm 0,87$ \\
\hline \multirow{3}{*}{... u poslovanju } & $\mathrm{Da}$ & $3,66 \pm 0,79$ & $2,5[1,5]$ & $4,0[1,5]$ \\
\hline & $\mathrm{Ne}$ & $3,42 \pm 1,09$ & $2,5[2,0]$ & $4,0[2,0]$ \\
\hline & & $\mathrm{p}=0,386^{\mathrm{a}}$ & $\mathrm{p}=0,933^{\mathrm{b}}$ & $\mathrm{p}=0,985^{\mathrm{b}}$ \\
\hline
\end{tabular}




\begin{tabular}{|c|c|c|c|c|}
\hline \multirow{3}{*}{$\begin{array}{l}\text {... za oglašavanje } \\
\text { slobodnih radnih } \\
\text { mjesta }\end{array}$} & $\mathrm{Da}$ & $3,98 \pm 0,64$ & $3,0[1,0]$ & $4,0[1,5]$ \\
\hline & $\mathrm{Ne}$ & $3,26 \pm 0,88$ & $2,0[2,0]$ & $4,0[2,0]$ \\
\hline & & $\mathbf{p}<0,001^{\mathrm{a}}$ & $\mathrm{p}=0,195^{\mathrm{b}}$ & $\mathrm{p}=0,714^{\mathrm{b}}$ \\
\hline \multirow{3}{*}{$\begin{array}{l}\text {... za informiranje o } \\
\text { potencijalnim kandi- } \\
\text { datima }\end{array}$} & $\mathrm{Da}$ & $4,0[1,11]$ & $2,75[1,5]$ & $3,5[1,5]$ \\
\hline & $\mathrm{Ne}$ & $3,42[0,96]$ & $2,25[2,0]$ & $4,0[2,0]$ \\
\hline & & $\mathrm{p}=\mathbf{0 , 0 0 3}^{\mathrm{b}}$ & $\mathrm{p}=0,323^{\mathrm{b}}$ & $\mathrm{p}=0,339^{b}$ \\
\hline \multicolumn{5}{|c|}{$\begin{array}{l}\text { Rezultati su iskazani kao aritmetička } \\
\text { medijan i interkvartilni raspon } \mathrm{C} \text { [IQ] }\end{array}$} \\
\hline
\end{tabular}

Izvor: priprema autorica

Značajna razlika u ocjeni faktora korisnost je utvrđena s obzirom na dosadašnju/trenutnu praksu korištenja društvenih mreža za oglašavanje slobodnih radnih mjesta te za informiranje o potencijalnim kandidatima.

Kako je vidljivo iz tablice 1 (poglavlje metodologija) poduzeća se razlikuju prema nekim karakteristikama te je istraženo postoje li značajne razlike u stavovima prema korištenju društvenih mreža u procesu pribavljanja i selekcije kadrova s obzirom na te karakteristike. Rezultati su prikazani u tablici 5.

Tablica 5.

\begin{tabular}{|c|c|c|c|c|}
\hline & & Korisnost & Presudnost & Pouzdanost \\
\hline \multirow{4}{*}{$\begin{array}{c}\text { Razdoblje } \\
\text { osnivanja po- } \\
\text { duzeća }\end{array}$} & prije 1990. god. & $3,57[1,61]$ & $2,25[1,13]$ & $4,0[2,0]$ \\
\hline & 1990. - 2000. god. & $3,57[0,86]$ & $2,5[1,5]$ & $4,0[1,5]$ \\
\hline & nakon 2000. god. & $3,71[1,43]$ & $2,0[2,0]$ & $3,5[1,5]$ \\
\hline & & $\mathrm{p}=0,633^{\mathrm{b}}$ & $\mathrm{p}=0,514^{\mathrm{b}}$ & $\mathrm{p}=0,960^{\mathrm{b}}$ \\
\hline \multirow{5}{*}{$\begin{array}{l}\text { Broj zaposle- } \\
\text { nih }\end{array}$} & manje od 10 & $3,63 \pm 0,83$ & $2,25[2,0]$ & $4,25[2,0]$ \\
\hline & između 10 i 50 & $3,49 \pm 0,89$ & $2,5[1,75]$ & $3,75[1,0]$ \\
\hline & između 50 i 250 & $3,52 \pm 0,94$ & $2,5[1,5]$ & $3,5[1,5]$ \\
\hline & više od 250 & $3,84 \pm 0,69$ & $2,25[1,75]$ & $3,75[1,5]$ \\
\hline & & $\mathrm{p}=0,650^{\mathrm{a}}$ & $\mathrm{p}=0,885^{\mathrm{b}}$ & $p=0,674^{b}$ \\
\hline \multirow{4}{*}{$\begin{array}{l}\text { Oblik vlasniš- } \\
\text { tva }\end{array}$} & Državno & $4,1 \pm 0,64$ & $2,5[2,13]$ & $4,5[1,38]$ \\
\hline & Privatno & $3,55 \pm 0,86$ & $2,5[1,5]$ & $3,5[1,5]$ \\
\hline & Mješovito & $3,91 \pm 0,86$ & 2,0 & 4,0 \\
\hline & & $\mathrm{p}=0,271^{\mathrm{a}}$ & $\mathrm{p}=0,810^{\mathrm{b}}$ & $\mathrm{p}=0,418^{\mathrm{b}}$ \\
\hline \multirow{3}{*}{$\begin{array}{l}\text { Vlasnička } \\
\text { struktura }\end{array}$} & domaći vlasnici & $3,62 \pm 0,92$ & $2,5[1,5]$ & $4,0[2,0]$ \\
\hline & strani vlasnici & $3,79 \pm 0,57$ & $3,0[2,0]$ & $3,5[1,0]$ \\
\hline & mješovito vlasništvo & $3,35 \pm 0,70$ & $2,0[1,5]$ & $4,0[1,5]$ \\
\hline
\end{tabular}




\begin{tabular}{ccccc}
\hline & & $\mathrm{p}=0,559^{\mathrm{a}}$ & $\mathrm{p}=0,123^{\mathrm{b}}$ & $\mathrm{p}=0,326^{\mathrm{b}}$ \\
\hline $\begin{array}{c}\text { Postoji odjel } \\
\text { ljudskih re- } \\
\text { sursa }\end{array}$ & $\mathrm{da}$ & $3,61 \pm 0,85$ & $2,25[1,63]$ & $3,5[1,13]$ \\
& ne & $3,62 \pm 0,85$ & $2,5[1,5]$ & $4,0[1,88]$ \\
& & $\mathrm{p}=0,952^{\mathrm{c}}$ & $\mathrm{p}=0,749^{\mathrm{d}}$ & $\mathrm{p}=0,085^{\mathrm{d}}$ \\
\hline \multirow{2}{*}{ Djelatnosti } & Sekundarne & $3,36 \pm 1,0$ & $2,5[1,0]$ & $3,5[1,0]$ \\
& Tercijarne & $3,68 \pm 0,78$ & $2,5[2,0]$ & $4,0[1,5]$ \\
\cline { 2 - 5 } & Kvartarne & $3,82 \pm 0,85$ & $3,0[1,5]$ & $4,5[2,0]$ \\
\hline
\end{tabular}

Rezultati su iskazani kao aritmetička sredina i standardna devijacija $\mathrm{M} \pm \mathrm{SD}$ ili kao medijan i interkvartilni raspon C [IQ]

$\mathrm{a}$ - ANOVA; $\mathrm{b}$ - Kruskal-Wallis $\mathrm{H}$ test; $\mathrm{c}-\mathrm{t}$ test za nezavisne uzorke; $\mathrm{d}$ - MannWhitenay U test

Izvor: priprema autorica

Značajna razlika u ocjeni istraživanih faktora nije utvrđena niti kod jedne karakteristike.

\section{RASPRAVA}

Očekivano, u uzorku postoji dio poduzeća koja još uvijek u svom poslovanju ne koriste društvene mreža što automatski implicira da ih ne koriste ni u kontekstu menadžmenta ljudskih potencijala. Od onih koji pak koriste društvene mreže $\mathrm{u}$ poslovanju samo dio ih dovodi u vezu s menadžmentom ljudskih potencijala dok ih ostali najvjerojatnije koriste kao marketinški kanal u svrhu promocijskih aktivnosti.

Polovina ispitanih poduzeća navodi da na društvenim mrežama objavljuje slobodna radna mjesta, dok ih se skoro pa isto polovina na društvenim mrežama informira o potencijalnim kandidatima. Ova činjenica pokazuje da su društvene mreža u Bosni i Hercegovini prepoznate kao pomoć u procesu pribavljanja i selekcije kadrova, no s obzirom na udio poduzeća koja ih koriste još uvijek nedovoljno. Ono što se usuđujemo zaključiti je da i ta poduzeća nisu u potpunosti iskoristila sve potencijale društvenih mreža u procesu upravljanja ljudskim potencijalima, onako kako to rade velike svjetske kompanije. Osnova za to su između ostalog i ocjene zadovoljstva dosadašnjeg iskustva prilikom korištenja društvenih mreža. Prosječne ocjene su ispod četiri, variraju, što pokazuje da postoji prostor za poboljšanja, kako u zastupljenosti i intenzitetu korištenja tako i korisničkom iskustvu. Naravno, treba napomenuti da nisu istraživani razlozi takvih ocjena korisničkog iskustva, a pitanje zašto je tako otkriva niz mogućih razloga (nedovoljno znanje, pasivnost $\mathrm{i}$ dr.). 
Razmišljajući o dobivenim rezultatima, konkretnije o omjeru poduzeća korisnika i nekorisnika društvenih mreža za potrebe menadžmenta ljudskim potencijalima postavlja se pitanje ,što nedovoljno korištenje društvenih mreža u menadžmentu ljudskih potencijala znači za poslodavce, a što za posloprimce?

S jedne strane za poslodavce bi to mogao biti propust jer neće prikupiti sve informacije o kandidatu koje bi mogle biti važne, a s druge strane, imajući na umu šta sve ljudi, posebno mladi, objavljuju na društvenim mrežama, za kandidate je možda olakotna okolnost što poslodavci neće pogledati šta su sve objavili.

Rezultati pokazuju da poduzeća istražujući svoje kandidate naglasak stavljaju na informacije koje se dovode u vezu s poslovnim karakteristikama ispitanika - prethodni posao, stupanj obrazovanja, preporuke, no dio ispitanika navodi da pregledavaju i druge informacije. Za pretpostaviti je da to čine kako bi stekli širi dojam o osobi koju će eventualno zaposliti. No, ovdje se nameće pitanje, je li stvarno točno ono što je netko objavio o sebi, treba li neke šale shvatiti ozbiljno, govori li lista njegovih prijatelja na društvenim mrežama išta o njegovom karakteru i sl. Navedeno je jako subjektivno, no da prilikom objavljivanja na društvenim mrežama treba dobro razmisliti govori i činjenica da banke prilikom odobravanja kredita provjeravaju prijatelje na društvenim mrežama svakog tražitelja kredita. Stoga se prilikom svake sljedeće objave treba sjetiti da vas i naizgled bezazlena šala može stajati posla.

Kako je u rezultatima prikazano stavovi ispitanika su istraženi kroz tvrdnje koje su ,pretočene“ $u$ dimenzije te se istražilo koliko ispitanici društvene mreže smatraju korisnima prilikom zapošljavanja, koliko one imaju presudnu važnost te koliko su pouzdani podaci i informacije koje one nude. Sukladno rezultatima o korištenju i ocjene ovih tvrdnji su relativno niske. Navedeno ukazuje da ispitanici smatraju da društvene mreže mogu biti od koristi prilikom upoznavanja kandidata za posao te da imaju i određenu razinu pouzdanosti, no niska ocjena dimenzije presudnost pokazuje da društvene mreže još uvijek ne igraju važnu ulogu u procesu pribavljanja i selekcije zaposlenika u poduzećima u Bosni i Hercegovini (barem ne u uzorkovanim poduzećima).

Istraživanje je pokazalo da značajne razlike u ocjeni istraživanih dimenzija postoje kod dimenzije korisnost i to s obzirom na dosadašnju/trenutnu praksu korištenja društvenih mreža kako za oglašavanje slobodnih radnih mjesta tako i za informiranje o potencijalnim kandidatima. Ispitanici koji dolaze iz poduzeća koja aktivno koriste društvene mreže su korisnost značajno bolje ocijenili nego ispitanici čija poduzeća ih ne koriste. Ovo pokazuje da se praktična vrijednost i koristi od društvenih mreža u kontekstu upravljanja ljudskim potencijalima mogu osjetiti tek nakon praktičnog iskustva. Kod ostalih dimenzija nisu nađene značajne razlike no prosječne ocjene ipak pokazuju da poduzeća s iskustvom u korištenju 
društvenih mreža u procesu zapošljavanja imaju bolje mišljenje o presudnosti i pouzdanosti društvenih mreža nego poduzeća koja ih ne koriste.

Cilj rada je bio i ispitati ima li značajnih razlika u dimenzijama s obzirom na karakteristike poduzeća, no rezultati nisu pokazali razlike u stavovima poslodavaca što ne stvara prostor za značajniju raspravu, a imajući na umu veličinu i strukturu uzorka te način uzorkovanja bilo bi jako diskutabilno izvoditi konkretnije i generalnije zaključke apostrofirajući neke od karakteristika kao značajne prediktore stavova poduzeća.

Unatoč tome, razlike u prosječnim ocjenama istraživanih faktora pokazuju da i karakteristike poduzeća mogu igrati ulogu u primjeni društvenih mreža u procesu zapošljavanja, a što može biti smjernica za buduća istraživanja.

\section{ZAKLJUČAK}

Rezultati istraživanja pokazuju da poslodavci u Bosni i Hercegovini u svom poslovanju sve više koriste mogućnosti koje im pružaju društvene mreže pa tako i one koje se tiču procesa zapošljavanja, odnosno pribavljanja i selekcije novih zaposlenika. Istina je da te mogućnosti ne koriste u obujmu kako to rade poduzeća u razvijenijim zemljama, ali je činjenica kako sve više postaju svjesni da se radi o mediju koji donosi niz prednosti veznih prvenstveno uz skraćivanje vremena i snižavanje troškova zapošljavanja.

Razumljiva je i logična opreznost poslodavaca koja se odnosi na pouzdanost podataka i informacija koje se mogu pronaći na profilima potencijalnih kandidata i jasno je da ti izvori ne smiju biti presudni kod odluke o izboru zaposlenika, ali je isto tako jasno da se neke sposobnosti, osobine ličnosti i kompetencije mogu iščitati iz sadržaja koje kandidati objavljuju, prate, dijele, komentiraju ili lajkaju na društvenim mrežama.

Kao ograničenja istraživanja treba prvenstveno navesti veličinu i strukturu uzorka, način uzorkovanja te upoznatost s društvenim mrežama općenito. Korišteni uzorak ne dopušta donošenje općih zaključaka za Bosnu i Hercegovinu, no istraživanje je dalo temelje za razmatranje trendova u kontekstu upravljanja ljudskim potencijalima, posebno u funkciji pribavljanja i selekcije zaposlenika. U budućim istraživanjima prvenstveno treba povećati uzorak kako bi dobiveni rezultati bili relevantniji, ali ga i strukturirati prema karakteristikama jer bi neke od njih mogle utjecati na razlike u praksi i stavovima.

Osim toga, daljnje istraživačke aktivnosti trebaju uključiti i drugu stranu odnosno tražitelje posla kako bi se dobio uvid u njihovu praksu i njihove stavove. Na taj 
način će se dobiti uvid u stvarnu prasku korištenja društvenih mreža u procesu pribavljanja i selekcije zaposlenika, ali će se spoznati i prednosti i nedostatci što će omogućiti njihovo adekvatnije i objektivnije korištenje u kontekstu upravljanja ljudskim potencijalima.

\section{LITERATURA}

1. Boehle, S. (2000). Online recruiting gets sneaky. Training, 37(5), 66-74.

2. Cober, R. T., Brown, D. J., Blumental, A. J., Doverspike, D., \& Levy, P. (2000). The quest for the qualified job surfer: It's time the public sector catches the wave. Public Personnel Management, 29, 479-494.

3. Davison, H. K., Maraist, C. C., Hamilton, R. H., \& Bing, M. N. (2012). To screen or not to screen? Using the internet for selection decisions. Employee Responsibility and Rights Journal, 24, 1-21.

4. Fallaw, S. S. \& Kantrowitz, T. M. (2013). Global Assessment Trends Report, dostupno na https://www.shl.com/en/assessments/trends/global-assessment-trends-report/ (pristupano 15.9.2019.)

5. Hudson, K. (2019). Why You Need to Invest in a Social Recruiting Strategy, dostupno na https://www.jobvite.com (pristupano 15.9.2019.)

6. Jovandić, M. (2014). Selekcija kandidata putem društvenih mreža - za ili protiv, Sinteza, 1036-1039.

7. Kluemper, D. H., McLarty, B., \& Rosen, P. (2013). What can LinkedIn tell us about potential job applicants? Exploring the relationship between individual characteristics and LinkedIn use. Presented at the Society for Industrial and Organizational Psychology meeting, Houston, TX.

8. Kluemper, D.H., Mitra, A. \& Wang, S. (2016). Social Media Use in HRM, Research in Personnel and Human Resources Management, Volume 34, 153-207.

9. Orehovački, T. (2013). Metodologija vrjednovanja kvalitete u korištenju aplikacijama Web 2.0, doktorski rad, Sveučilište u Zagrebu, Fakultet organizacije i informatike, Varaždin

10. Pempek, T.A., Yermolayeva. Y.A. \& Calvert. S.L. (2009). College students' social networking experiences on Facebook, Journal of Applied Developmental Psychology, 3, 227-238.

11. https://www.moj-posao.net/Savjet/77341/Drustvene-mreze-su-privatna-stvar-ALI/55/ (pristupano 15.9.2019.)

12. http://www.shrm.org/research/surveyfindings/articles/pages/theuseofsocialnetworkingwebsitesandonlinesearchenginesinscreeningjobcandidates.aspx (pristupano 13.9.2019.) 


\title{
Lidija Lesko Bošnjak, PhD
}

University of Mostar, Faculty of Economics Mostar, B\&H

lidija.lesko@ef.sum.ba

\section{Mirela Mabić, MSc}

University of Mostar, Faculty of Economics, Mostar, B\&H

mirela.mabic@ef.sum.ba

\section{SOCIAL NETWORKS AND RECRUITING: EMPLOYERS' PRACTICES AND OPINIONS IN BOSNIA AND HERZEGOVINA}

Received: October 4, 2019

Accepted: November 30, 2019

Review

\begin{abstract}
The use of the Internet and social networks is an indispensable segment in business of modern organizations. Beside for promoting their activitities, employers increasingly use social networks for recruiting and selecting new employees. The main aim of the paper is to explore employers' practices and opinions in Bosnia and Herzegovina regarding the use and perception of social networks'values as one of the tools in recruitment process.

An empirical research was carried on over May and June 2019. The authors drew up questionnaire and distributed them online. 300 companies were invited to take part, 62 of them responded. Absolute and relative frequencies, measures of the descriptive statistics, were used for the presentation of the results. Significance of differences was tested by the independent sample t test, ANOVA, Mann-Whitney $U$ test and Kruskal-Wallis $H$ test. The study results show that even though $82 \%$ of employers state they exploit social networks in their doing business, just half of them recognize social networks as a valuable tool in the process of recruiting and selecting employees. The use of the services of the employment agencies, recruiting by recommendations, and having a base of potential candidates, are the reasons for some employers not to use social networks enough, while for some employers they are inadequate tools in the context of human resources management.
\end{abstract}


The size of the sample and familiarity with social networks in general should be primarily cited as the research limitations. The used sample does not provide for reaching general conclusions for Bosnia and Herzegovina, but the research creates the basis for understanding the status and trends regarding the use of social networks in the context of recruiting.

Keywords: social networks, recruitment, employers, Bosnia and Herzegovina;

JEL: O15, L86 